suffer from trachoma in rather a quiet form, and that in his experience the strain of school life causes an exacerbation of the disease when the discharge is highly contagious and may easily cause an epidemic of the disease in children who were formerly free from the disease. Then, again, the importance of high hypermetropia as a cause of squint cannot be overlooked. Myopia is fortunately rare in $\mathrm{Cuba}$, and in connexion with this he points out that the light there is, of course, very good. The results of ophthalmia neonatorum and of interstital keratitis are dwelt upon, as well as the value of spectacles as a cure for eyestrain and headache. Ruiz of Seville describes a single stitch operation for the advancement of a rectus muscle, which is ingenious and not very complicated. A paper by E. Wieden on Nicola's new treatment of trachoma calls attention to a subject of perennial interest, and we believe that very little is known in this country about this form of treatment which has arisen in Italy.

The remaining papers are mòstly short ones, clinical records of cases, and there is one by Espino on the history of ophthalmology in Venezuela.

The reviews of articles and of books follow the usual lines, as do those of the various societies. The obituary section contains notices of Sir James Mackenzie Davidson, of John Couper, of Mortimer Frank, and of Newton C. Steele, and of others.

It will be seen that the editor of the journal has spread his net widely; it is no easy task to furnish excerpts, of the world's ophthalmic literature and we congratulate him on the completion of his first volume.

R. R. JAMES.

\title{
CORRESPONDENCE
}

\section{ON A RARE FORM OF SUBCONJUNCTIVAL GRANULOMA IN CENTRAL CHINA}

To the Editor of the BRITISH JOURNAL OF OPHTHALMOLOGY.

SIR,-After reading Dr. McAll's paper in the last number of this Journal, I was struck with the possible resemblance to other forms, of elephantiasis that I had seen in Shanghai. I was fortunately able to discuss the matter with Sir Patrick Manson, the pioneer in this branch of research. He considers that the cause is 
almost certainly parasitic, either protozoal or helminthic. A careful blood examination would confirm this if definite eosinophilia was found. He did not think it would be found to be any of the known varieties of filaria, as I had thought might be the case.

I hope Dr. McAll may. give us some further account of his investigations of this hitherto unknown disease.

I am, Sir, yours truly,

E. Erskine Henderson.

LoNDON, W.

\section{OBITUARY}

Medicine deplores the loss of "one of her greatest sons-Sir William Osler, Regius Professor of Medicine in the University of Oxford-which took place after a short illness on December 29 , -1919, at Norham Gardens, Oxford, in his seventy-first year. The sixth son of the Rev. F. L. Osler, Sir William was born at Bondhead, Ontario, whither his father had gone as a missionary. He received his preliminary education in Toronto, and pursued his, medical studies at University College, London, and at Berlin, Vienna, and Leipsic, where the most advanced medical teaching was then to be found. At the early age of 25 he was appointed professor of the Institutes of Medicine at McGill University. For five years he held the professorship of clinical medicine at the University of Pennsylvania, and was then called to be professor of medicine in the Johns Hopkins University at Baltimore, where his work and example effected a remarkable improvement in the standing of the medical school. In 1905 he was appointed Regius Professor of Medicine at Oxford in succession to Sir John Burdon-Sanderson. No choice could have been happier in the interests of the Oxford Medical School. His sympathies with the young man desirous of learning were widely recognized, and will be remembered with gratitude by those who had the privilege of working under him. Sir William was distinguished in many walks of life. He was a man of letters, a ripe classical scholar, a voluminous writer, and a great physician. $\mathrm{He}$ was created a baronet in 1911. His connection with ophthalmology was long and intimate. He was an original member of the Oxford Ophthalmological Congress, and he was a well known and sympathetic figure at its meetings. $\mathrm{He}$ was a counoillor of the Congress, and the large number of Americans who attended the meetings of that body gave him many opportunities of renewing 